\title{
A szovjet flotta új háborúra történő felkészülésének tervei (1936-1956) u.resz
}

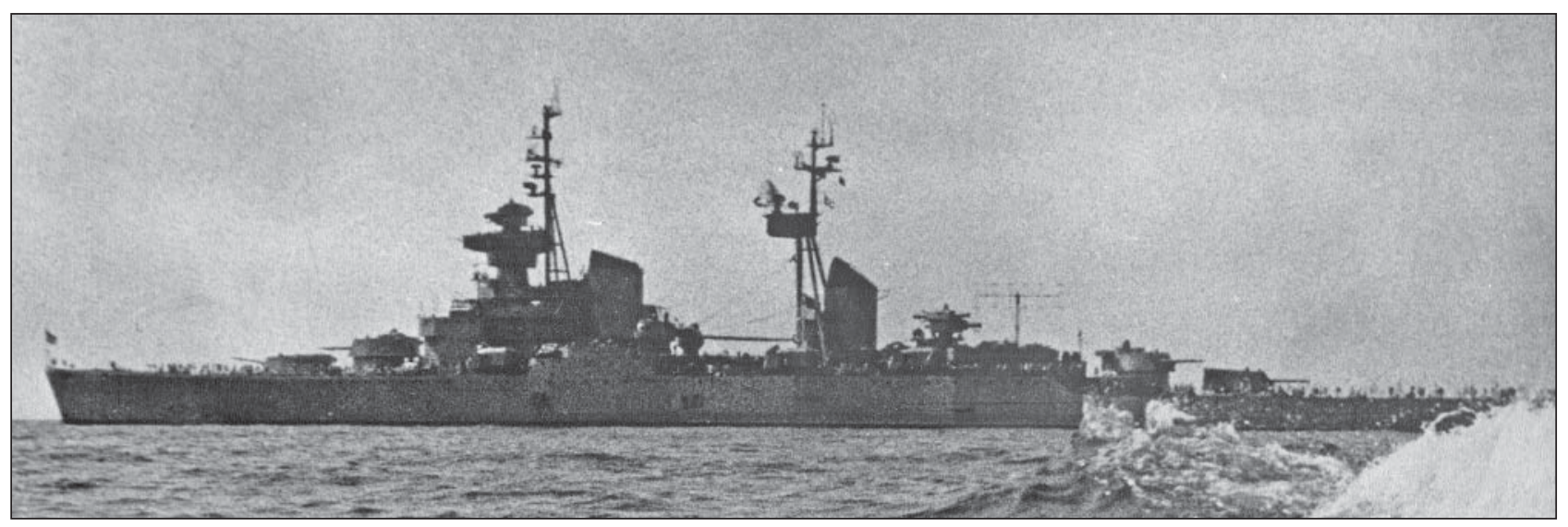

14. ábra. A SZVERDLOV „nehéz”cirkáló osztály egyik egysége, amely valójában csak egy könnyű cirkáló páncélzatával és elégtelen fegyverzettel rendelkezett

\section{AZ ÚJ FLOTTAPROGRAM}

A „nyugat” elleni felszabadító háború nem merült feledésbe. A SzU jobb földrajzi pozícióba jutott, elvett finn területeket, megszállta Észtországot, Lettországot, Litvániát, Kelet-Poroszországot, Besszarábiát, Bukovinát, Lengyelország keleti felét. Megszállva tartotta Kelet- és KözépEurópa öt országát, itt bábkormányai gyakorolták a hatalmat, kezében volt KözépNémetország. Gyakorlatilag felzárkózott Nyugat-Európa határszéleire.

Közbejött azonban az atomfegyver és az USA monopóliuma. Ezért már 1945 nyarán elrendelték a szovjet nukleáris ipar gyorsított kiépítését, úgymond „kerül, amibe kerül”. lgy 1949 augusztusában robbantották az első kísérleti szovjet atomfegyvert, de ennek az volt az ára, hogy a flotta kevesebbet kapott, mint az 1935-1945 közötti időszakban.

Ettől függetlenül 19381945 között 23 terv készült kis, közepes és nagy repülögép-hordozó építésére. Egyet sem rendeltek meg, de 1945 júliusában Sztálin kiadta az irányelvet a flottaépítési tervre. 1945. november 25-én megjelent az 1946-1955-re
2. táblázat. A szovjet csatahajók föbb adatai I.

\begin{tabular}{|c|c|c|}
\hline & $\begin{array}{l}\text { SZOVJETSZKIJ SZOJUZ } \\
\text { osztály csatahajó }\end{array}$ & $\begin{array}{c}\text { KRONSTADT } \\
\text { osztály csatacirkáló }\end{array}$ \\
\hline Vízkiszorítás (t) & $59150 / 65150$ & $35240 / 38360$ \\
\hline Hosszúság (m) & 271,0 & 248,0 \\
\hline Szélesség (m) & 38,9 vagy 38,7 & 31,0 \\
\hline Merülés (m) & 10,1 & n. a. \\
\hline Gépészet & $\begin{array}{c}3 \text { gőz TU + } 12 \text { kazán } \\
210 \text { 000 LE/231.000 LE }\end{array}$ & $\begin{array}{c}3 \text { gőz TU + } 12 \text { kazán } \\
210000 \text { LE }\end{array}$ \\
\hline Max. seb. (csomó) ${ }^{\star}$ & 28 & 33 \\
\hline Páncélzat (mm) & $\begin{array}{c}425 / 225 \\
499\end{array}$ & $\begin{array}{c}270 / 90 \\
230\end{array}$ \\
\hline Fegyverzet & $\begin{array}{c}9 \times 406 \mathrm{~mm}(3 \times 3) \\
12 \times 152 \mathrm{~mm}(6 \times 2) \\
8 \times 100 \mathrm{~mm}(4 \times 2) \\
32 \times 37 \mathrm{~mm} \text { lgv.; } 8 \times 12,7 \mathrm{~mm} \mathrm{lgv} .\end{array}$ & $\begin{array}{c}9 \times 305 \mathrm{~mm}(3 \times 3) \\
\text { vagy } 6 \times 380 \mathrm{~mm}(3 \times 2) \\
8 \times 152 \mathrm{~mm}(4 \times 2) \\
4 \times 100 \mathrm{~mm} ; 7 \times 37 \mathrm{~mm} \text { lgv. }\end{array}$ \\
\hline Rendelve & $4 \mathrm{db}$ & $3 \mathrm{db}$ \\
\hline Épült & $4 \mathrm{db}$ - befejezetlen & $3 \mathrm{db}$ - befejezetlen \\
\hline
\end{tabular}

* 1 csomó $=1852 \mathrm{~m} / \mathrm{h}=1,852 \mathrm{~km} / \mathrm{h}$.

szóló flottaépítési terv, amelyben sem hordozó, sem csatahajó nem szerepelt.

Szerepelt viszont tengeralattjáró bőven. Függetlenül attól, hogy soha nem ismerték el a német Dönitz-féle stratégia átvételét, elkezdték megvalósítani. A nagyobb egységekből az 1938-1944 között nehezen, de megépült a M. GORKIJ osztály hat cirkálója, ehhez jött hozzá a CSAPAJEV 
3. táblázat. A szovjet csatahajók főbb adatai II.

\begin{tabular}{|c|c|c|}
\hline & SZTÁLINGRÁD osztály & SZVERDLOV osztály \\
\hline Terv & projekt 82 csatacirkáló & projekt 68 bis könnyűcirkáló \\
\hline Vízkiszorítás (t) & $36500 / 42300$ & $14290 / 17970$ \\
\hline Hosszúság (m) & 273,6 & 210,1 \\
\hline Szélesség (m) & 32,1 & 22,1 \\
\hline Merülés (m) & 9,2 & 7,8 \\
\hline Gépészet & 4 gőz TU, 12 kazán, 280000 LE & 2 gőz TU, 6 kazán, 110000 LE \\
\hline Max. seb. (csomó)* & 35,0 & 33,7 \\
\hline Fegyverzet & $\begin{array}{c}9 \times 305 \mathrm{~mm} ; 12 \times 130 \mathrm{~mm} ; \\
24 \times 45 \mathrm{~mm} \text { lgv.; } 40 \times 25 \mathrm{~mm} \\
\text { lgv.; } 12 \times 37 \mathrm{~mm} \text { lgv }\end{array}$ & $\begin{array}{c}12 \times 152 \mathrm{~mm} ; 12 \times 100 \mathrm{~mm} ; \\
32 \times 37 \mathrm{~mm} \text { lgv.; } 10 \times 533 \mathrm{~mm} \text { TR; } \\
140-250 \mathrm{db} \text { akna lehetséges. }\end{array}$ \\
\hline Legénység (fő) & 1712 & 1270 \\
\hline Rendelve & $3 \mathrm{db}$ & $24 \mathrm{db}$ \\
\hline Épült & $\begin{array}{c}\text { 1949-1954 } 1 \text { db, } \\
1 \text { db elkezdve, } \\
19542 \text { db lebontva }\end{array}$ & $\begin{array}{l}\text { 1950-60 között } 14 \mathrm{db} \\
\text { törölve } 4 \mathrm{db} \\
\text { vízre bocsátva, } \\
\text { majd lebontva } 5 \mathrm{db} \\
\text { sólyán lebontva } 1 \mathrm{db}\end{array}$ \\
\hline
\end{tabular}

1 csomó = 1 tengeri mérföld/h = 1,852km/h. vették munkába. Nincs válasz arra a kérdésre, hogy miért nem alakították át a Leningrádban félbehagyottan álló két korábbi hajótestet.

A munka mindenesetre beindult és 1953 márciusáig ütemesen zajlott. Ekkor J. V. Sztálin 1953. március 5-én váratlanul meghalt, kijelölt utódja nem volt. A hatalmi harc nyomban megindult az SZKP vezetésében. Bulganyin akkor a minisztertanács elnökhelyettese, már 1953. március 23-án aláírta a parancsot a nagy hajók építésének leállításáról. Ezzel 160 millió aranyrubelt dobott ki az ablakon. Pár nap múlva megjelent a parancs a SZVERDLOV osztály 4 cirkálójának törléséről, és arról, hogy $100 \mathrm{db}$ Pr 613-as tengeralattjáró építését el sem kezdik.

A belharcok során L. Beriját, az NKVD főnökét, több főtisztjével együtt kivégzik. Malenkov, aki 1941-től 1957-

osztály 4 db nagyobb cirkálója, amelyeket elkezdtek, de a háború után 1949-1951 között fejeztek be.

Ez prototípusa volt a hasonló SZVERDLOV osztály hajóinak, amely a legérthetetlenebb típus a nagy szovjet hadihajók között. Egy 1517000 t-s nehéz cirkáló nagyságú hajótest, egy könnyű cirkáló vékony páncélzatával és $4 \times 3$ db 152 mm-es lövegtoronnyal ellátva. Ez utóbbi német átvétel 1945-ből. Ez az a kategória, amit semmire nem lehet használni. Ebből eredetileg $24 \mathrm{db}$ építése volt a tervben, de csak 18 készült el, 4-et töröltek.

1948-1954 között 15 db épült meg, 3 db félkész egységet 1960 körül lebontottak, 4 hajót töröltek. A megmaradtból 1 db-ot eladtak Indonéziának (IRIAN), 2 db-ot légvédelmi rakétákkal átépítettek, a többi módosításokkal, de az 1990-es évekig létezett. 2000 után valamennyit lebontották.

\section{Az ÉPITÉSI PROGRAM 1946-1955}

3 db csatacirkáló (SZTÁLINGRÁD oszt.) Projekt 82; $24 \mathrm{db}$ cirkáló (SZVERDLOV oszt.) Projekt 68 bis;

4 db cirkáló CSAPAJEV osztály (Projekt 68K) befejezése; 300 db Projekt 613 (W osztály) D/E tengeralattjáró;

50 db M.V. bis osztályú tengeralattjáró;

$65 \mathrm{db}$ torpedóromboló (Pr. 56 és Pr. 30 bis);

50 db RIGA osztályú partvédő, 1952-58 között;

12 db KOLA osztályú partvédő,1953-56 között;

30 db Zulu (Pr. 611) osztályú nagy tengeralattjáró;

$13 \mathrm{db}$ Quebec (Pr. 615) osztályú tengeralattjáró.

Összesen: $551 \mathrm{db}$ hajóegység (van $605 \mathrm{db}$-os adat is).

A Pr. 82 osztályú csatacirkálók J. V. Sztálin utasítására kerültek be a programba. A főtervező V. Dikovic 1948-ban átdolgozta a háború előtti KRONSTADT osztály terveit, ezt

ig a KB-ban a politikai bizottság titkárhelyettese volt (Sztálin mögött), 1953-1955-ig a minisztertanács elnöke is. 1957-ben teljes a bukása, belső száműzetésbe került. Bulganyin 1955-től 1958-ig a minisztertanács elnöke, 1958-ban leváltva, teljes bukás lett a sorsa. Ny. Sz. Hruscsov a KB titkára, 1955-től főtitkára lett, 1958-tól a minisztertanács elnöke is.

Eközben a félkész hajók épülnek, de számos darabszám csökkent. A Pr. 68 bis-ből 4 egységet töröltek, 1951-1958ig 12 készült el, 6 épülőben volt, 2 lebontásra került. Az

16. ábra. Az egyetlen félkész SZTÁLINGRÁD osztályú csatacirkáló célhajóként végezte 1955-ben

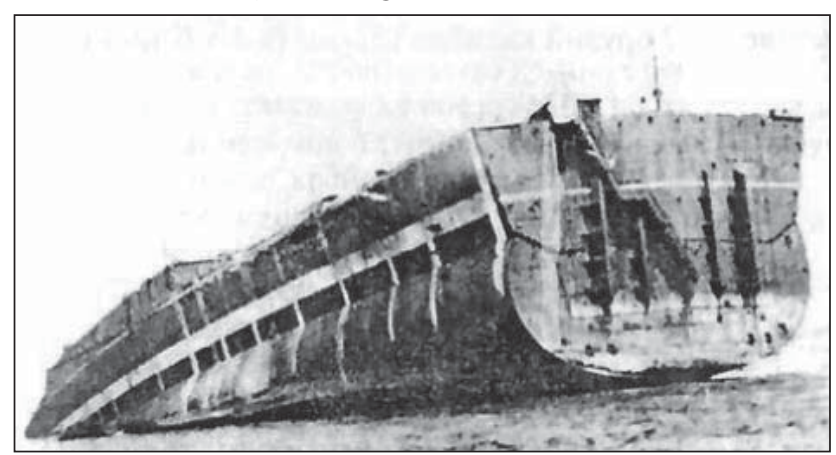




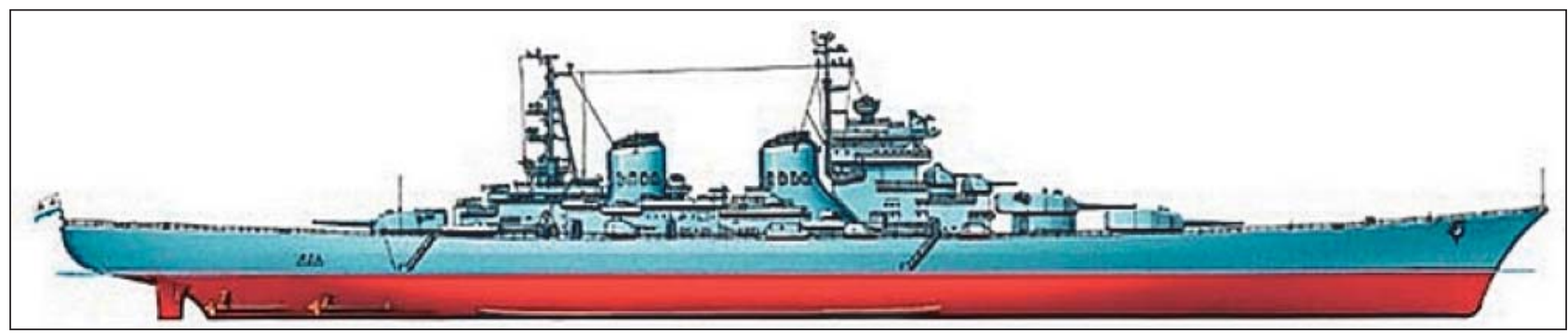

\section{7. ábra. A SZTÁLINGRÁD grafikája}

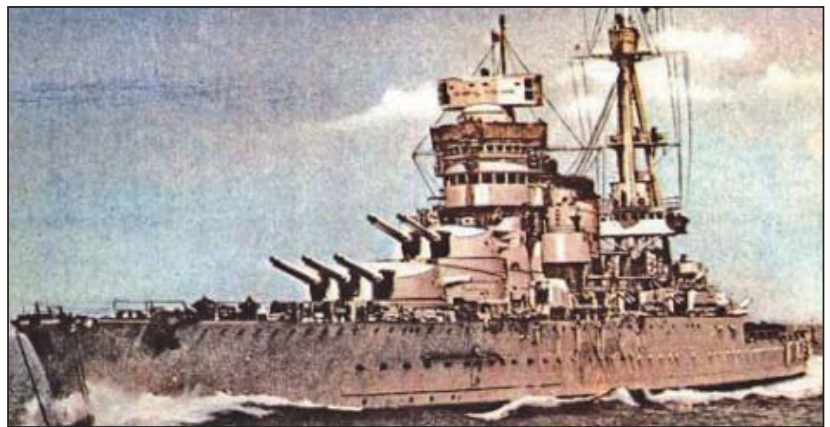

18. ábra. Az olasz eredetű NOVOROSSIJSK csatahajó. A II. világháborúban GUILIO CESARE néven teljesített szolgálatot az olasz haditengerészetnél, majd 1945-ben hadizsákmányként a Szovjetunióhoz került

50 db M.V. osztályú tengeralattjáróból csak 10 épült meg, a Pr. 613-asból 195 db után leállt a gyártás. A Pr. 611esböl $27 \mathrm{db}$ épült, de csak $22 \mathrm{db}$-ot fejeztek be.

\section{A hadÁszati helyzet megváltozása}

Bár a Szovjetunió már 1949-től rendelkezett atomtöltettel, ez kísérleti jellegű volt, 1951-ben volt bombája, 1953 nyarán volt ledobható fegyvere a Tu-4 gépről. Ez nem volt elegendő, erőltetett ütemben folyt a nukleáris üzemek építése és folytak a ballisztikus rakétakísérletek a német V-2 nyomán. Ennek szovjet változatai az R-1 és R-2 voltak, de ehhez a töltettömeget és a méretét csökkenteni kellett. Mindez sok forrást emésztett fel, a flottára jóval kevesebb pénzösszeg jutott.

A nukleáris fölény és korszerűség a nyugaté volt, a tengeralattjáró-felderítés és -elhárítás alaposan fejlődött, kilátás sem volt Sztálin 1950-es tervének realizálására. Ekkor került az élre Gorskov tengernagy, akit Hruscsov 20 éven át hagyott működni.

1948-től 51-ig ellentengernagy, a feketetengeri flotta vezérkari főnöke, 1951-től 1955ig főparancsnoka, 1956-ban, 45 évesen tengernagy, 1967-től flottatengernagy.

Ő húsz év alatt kialakított egy óceáni flottát, amely képes volt megjelenni a Földközi-tengeren és számos külföldi országba eljutott Kubától Vietnámig, de igazi nagy egységei nem voltak.

A nagy egységek sorsa az alábbi volt. A SZTÁLINGRÁD építését 1949. szeptember 25-én kezdték meg Nyikolajevben, a munka 1953. március 23-án leállt, 1954. február 16-án vízre bocsátották, hogy ne foglalja el a sólyát. Átalakításra volt terv, nem valósult meg, célhajóként használták, majd lebontották. A MOSZK-

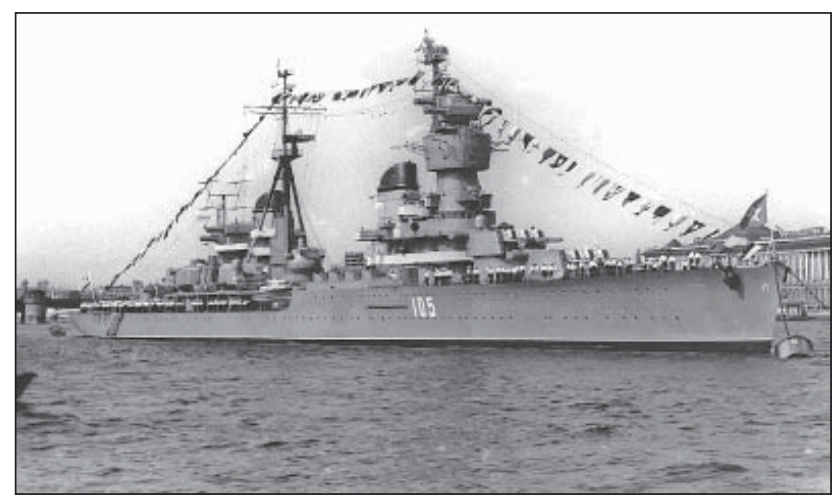

19. ábra. CSAPAJEV osztályú cirkáló a Neva folyón, 1957 után, már radarral ellátva

VA építése 1951-ben kezdődött Leningrádban. 1953. március 23-án a munka leállítva, még a sólyán lebontották. Az ARHANGELSZK építését 1952-ben kezdték Szeverodvinszkben (ex Molotovszk). Az építés 1953-ban leállt, még a sólyán lebontva.

Közben az 1946 után Olaszországtól átvett NOVOROSZIJSZK (ex GUILIO CESARE) csatahajó, Szevasztopol kikötőjében állva, 1955. július 29-én előzmény nélkül felrobbant. A legénység nagy része meghalt, igazi oka máig sem derült ki.

A Pr. 68K CSAPAJEV cirkáló osztály négy egységét 1948-1949-ben tovább építették, a névadó 1961-ig szolgált, akkor lebontották. A ZSELEZNYAKOV-ot 1950-ben adták át, 1965-ig szolgált, lebontották. A CSKALOV iskolahajó volt, 1950-ben adták át, 1955 után KOMSZOMOLEC néven szolgált 1960-ig, majd lebontották. A FRUNZE

20. ábra. A CSAPAJEV osztály egyik hajója, a KOMSZOMOLEC

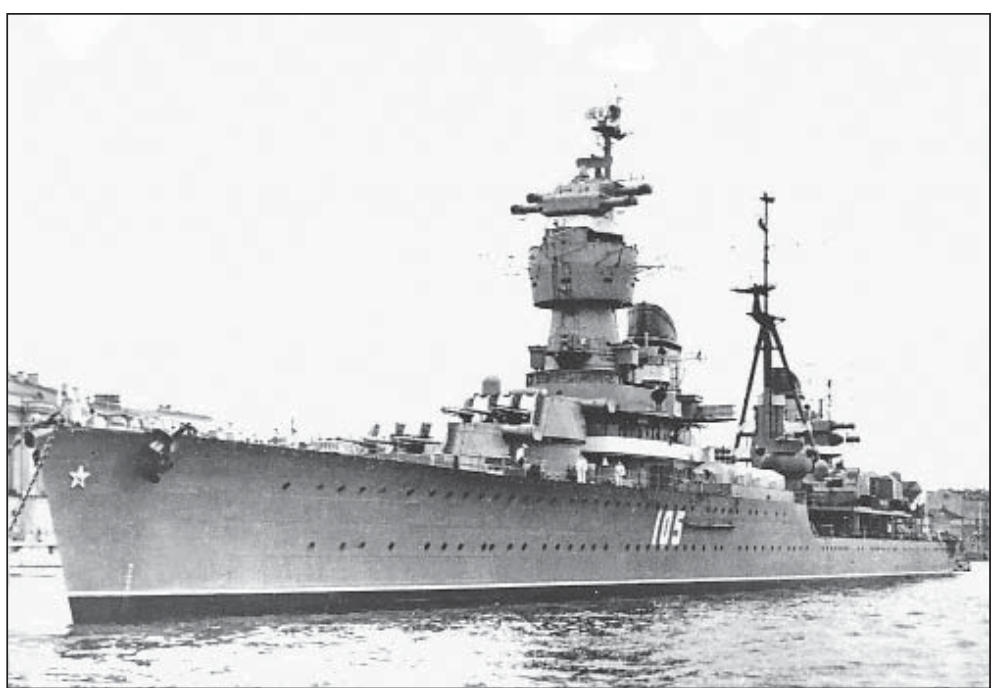




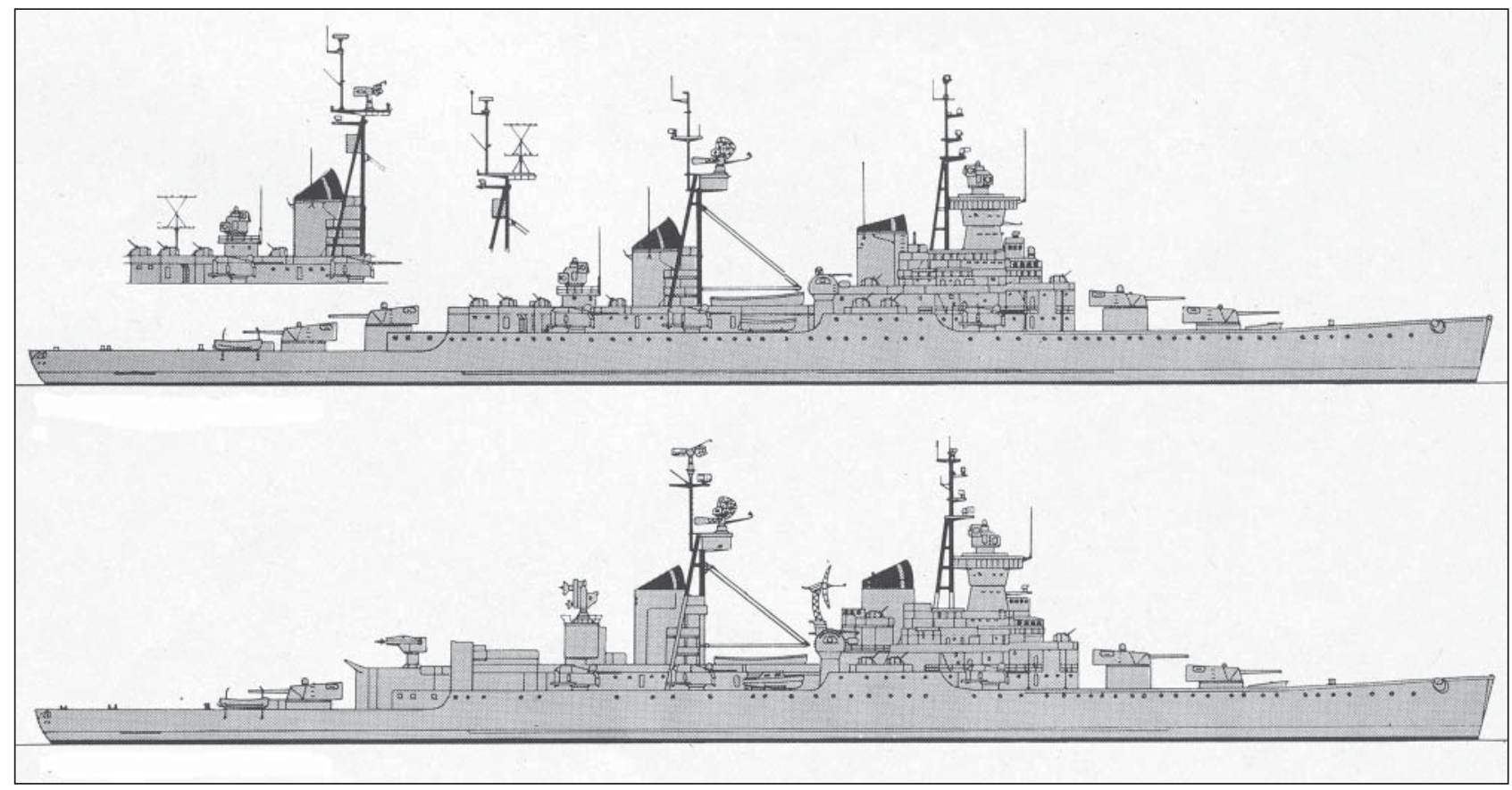

\section{1. ábra. A SZVERDLOV és a DZSERZSINSZKIJ cirkálók rajzai}

1950-ben átadva, későbbi neve KUJBISEV, rekord ideig, 27 évig szolgált, 1977-ben vonták ki, lebontották. Az osztály 5. egysége a nyikolajevi gyárban maradt 1941 nyarán, a testet 1946 után lebontották.

A tengeralattjárók nagy részét a leningrádi, gorkiji, nyikolajevi és Komszomolszk nad Amure-i üzemek gyártották. A háború végi zsákmányanyagból $4 \mathrm{db}$ VIIC, $1 \mathrm{db}$ IXC, $4 \mathrm{db}$ XXI és $1 \mathrm{db}$ XXIII osztályú német tengeralattjárót vettek át, ez összesen 10 db hajó. A XXI osztály szovjet gyártástechnológia szerinti szerényebb változata lett a Pr. 613 (W. oszt.), ebből 1951-1957 között 5 osztályban 194 db készült el. Ezekből 1955-től exportáltak 58 db-ot. (Albánia $4 \mathrm{db}$, Bulgária $2 \mathrm{db}$, Kína $21 \mathrm{db}$, Kuba $1 \mathrm{db}$, Egyiptom $7 \mathrm{db}$, Indonézia $12 \mathrm{db}$, KNDK $2 \mathrm{db}$, Románia $4 \mathrm{db}$, Lengyelország $5 \mathrm{db}$ ). A maradék 136 db-ból 1955 után 14 db átépítésre került robotrepülőgépek hordozására. Több megoldást is kipróbáltak, 1, 2, 4 db konténer elhelyezésére, de ezek nem váltak be. Az igazi megoldás a hajótesten belüli elhelyezés volt. Ezek mellett 2 db fegyvertelen óceánkutató hajó lett. Érdekesség, hogy $5 \mathrm{db}$-ot átépítettek radaros előrejelző hajónak, amelyek azonban nem voltak sikeresek.

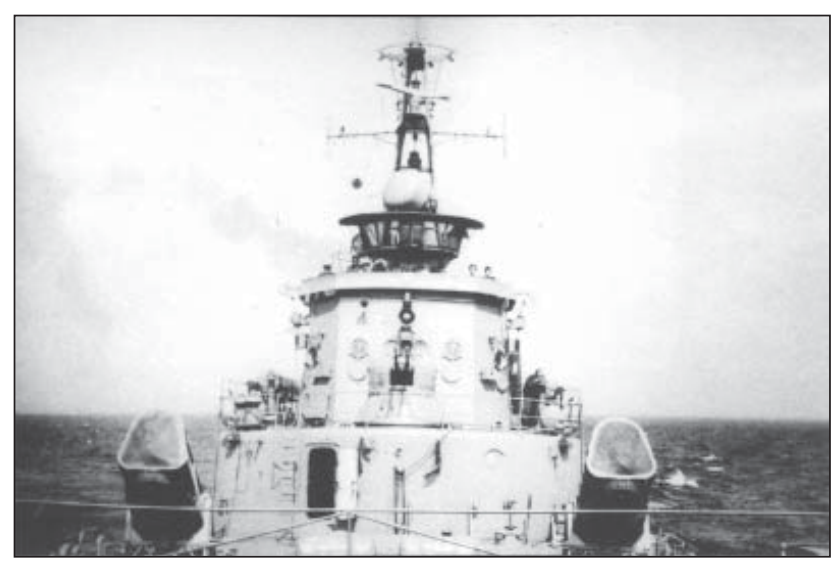

23. ábra. Partvédő hajó a korai robotrepülögépek konténereivel

A Pr. 611 (Zulu) nagy tengeralattjáróból 1952-1955 (vagy 1951-1957) között 27 db épült meg, a I.(AB), II.(P), III.(R) változatokban. A V. változat tornyát $2 \mathrm{db} S \mathrm{SN}-4$-es ballisz-

\section{2. ábra. G osztályú átépített rakétahordozó tengeralattjáró sérült toronnyal hazafelé tart}

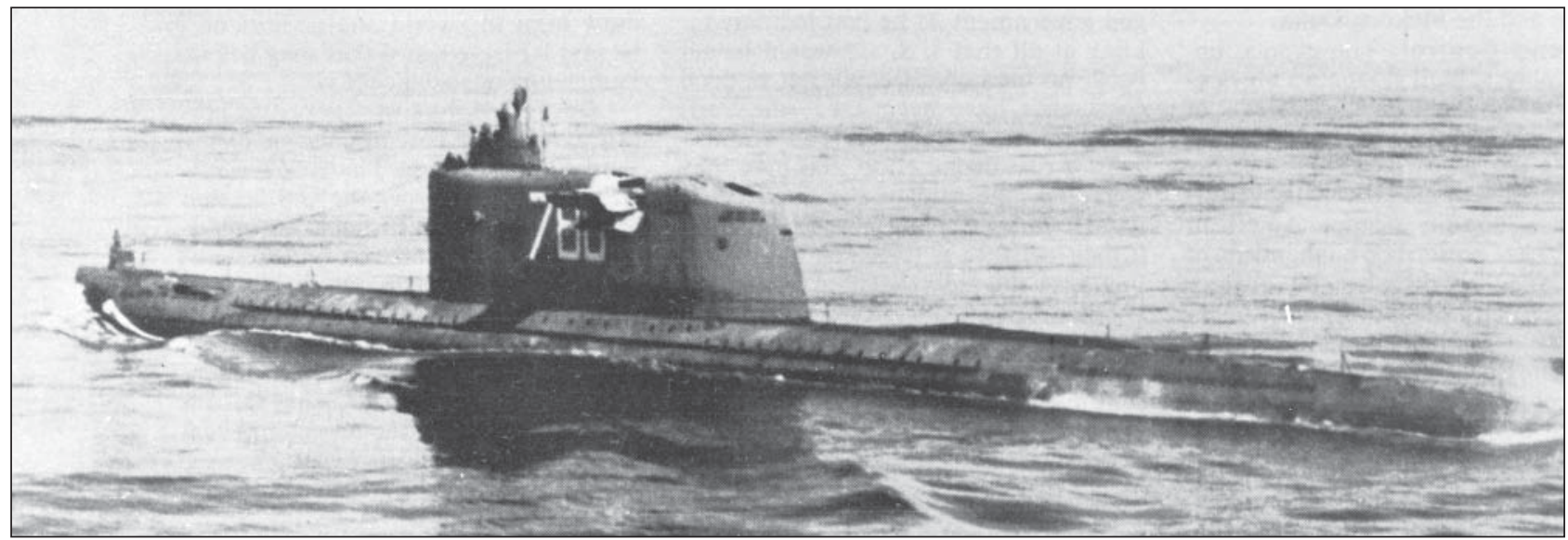




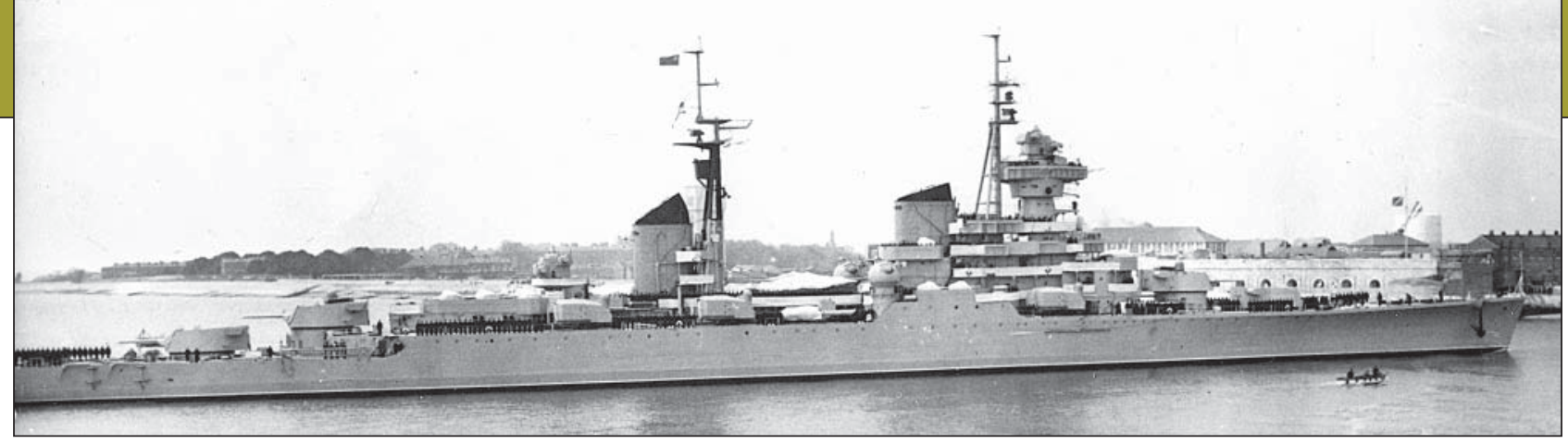

26. ábra. Az ORDZSONIKIDZE 1956-ban. Ezen a hajón utazott Hruscsov angliai látogatására az „enyhülés” jegyében

tikus rakéta hordozására építették át. Összesen hét hajóegység épült át 1956-1958 között hasonló módon, de rakétaindításkor a toronynak a víz felett kellett lennie. A rakéta 560 km hatótávolságú (Snark) típus volt.

A Pr. 615-ös (Quebec) típusból 19541957 között Leningrádban 13 db épült meg (van $40 \mathrm{db}-0$ adat is). Nem gyártották tovább, nem volt perspektivikus. Az R. osztályból (Romeo) 1957-1961 között $34 \mathrm{db}$ ismert, de csak $14 \mathrm{db}$ maradt a szovjet flottánál, 14-et Kínába, 6 db-ot Egyiptomba exportáltak.

A legnagyobb D/E-s típusból az F osztályból 1956-1967 között 49 db épült meg, ebből 4 db-ot Indiába exportáltak. $\mathrm{Az} 50$ db-ra tervezett régi $M$ (Maljutka) osztályból csak 10 db épült meg 1944-1952 között. Ebből 6 db M.V. típus Lengyelországba, 3 db M.201 típus Kínába került.

A rombolók helyzete igen vegyes képet mutatott. A TALLIN osztályból csak 1 db partvédő épült, ezt feladták. A Pr. 56 (Kotlin oszt.) rombolókból 1953-1956 között 27 db elkészült, de nem voltak vele megelégedve. Ezért 19571959 között Kildin osztály néven, négy példányát konténeres tengerészeti robotrepülőgépek hordozására átépítették. Ezután 1961-1969 között Kotlin I, II jellel légvédelmi

\section{4. ábra. A SZVERDLOV osztályú cirkáló egyik légvédelmi} lövege és tưzvezető radarja

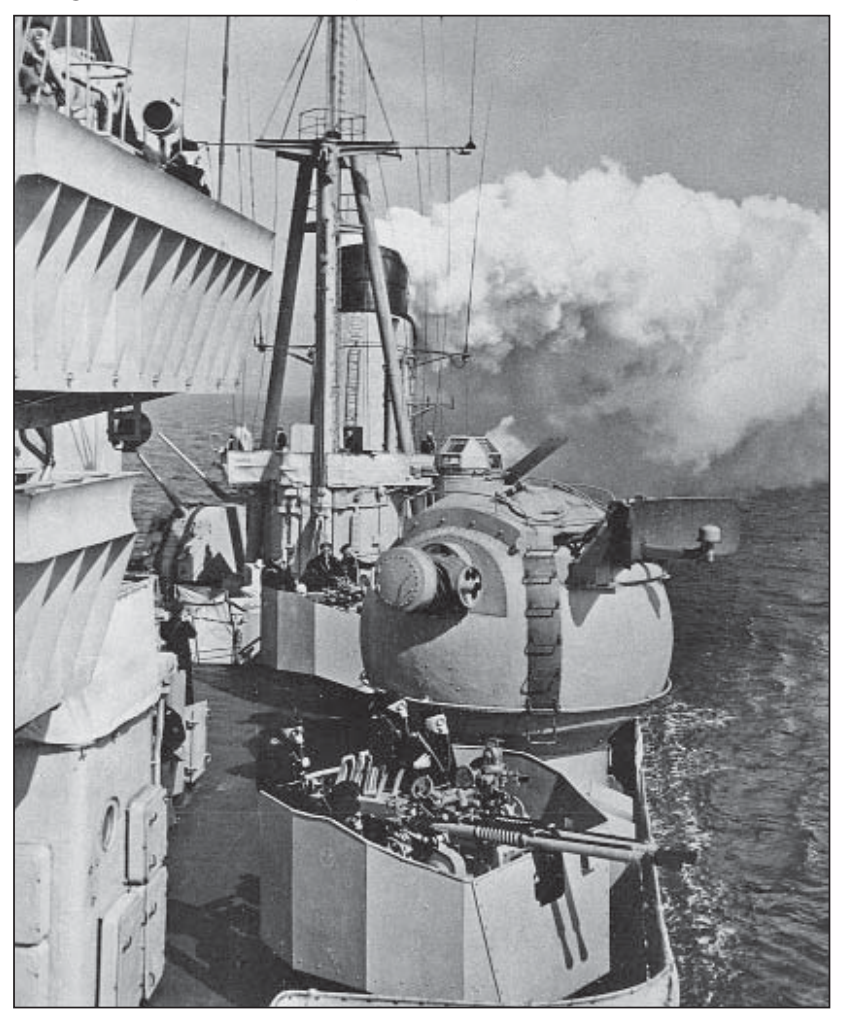

rakéták

A Krupnij osztály 1958-ban 4 példányban épült meg, de 1967-1968-ban hármat átépítettek légvédelmi rakétásra. A Pr. 30-as (Skory) osztály 1954-től épült, 55 db-ja ismeretes. Ebből 45 a szovjet, 4 az egyiptomi, 4 az indonéz $2 \mathrm{db}$ a lengyel flottához került. A Karsin osztály rakétafegyverzetű lett, de 4 példány 1967-es átépítése a Krupnij osztályból történt. Ez hordozott először $2 \times 2$ db-os légvédelmi rakétaindítót.

Elmondható, hogy az 1945-1953 között megépült 70 db romboló egyike sem maradt az eredeti állapotában.

A gyors elavulás a régi D/E-s hajókat hamar ócskavassá változtatta, megjelent a nukleáris hajtómű. Ny. Sz. Hruscsov 1958-tól az SZKP főtitkáraként és a minisztertanács elnökeként egyre nagyobb befolyást gyakorolt a fegyverfejlesztésre. O két fő szempontot tartott szem előtt: a nukleáris töltetű ballisztikus rakétákat és a nukleáris meghajtású tengeralattjárókat. Gorskov tengernagy vezényletével 20 éven át érvényesítette az akaratát. Ez már a Szovjetunió III. flottafejlesztési programja volt, de ez meghaladja jelen cikk kereteit.

\section{ForRÁsoK}

Siegfried Breyer: Schlachtschiffe und Schlachtkrezer 1955-1970 J.F. Lehmanns Verl. München, 1970.;

Weyers: Taschenbuch der Kriegsflotten 1940. J.F. Lehmanns Verl. München/Berlin, 1940. Neuanflage 1973.;

Weyers: Flottentaschenbuch 1954/55. J.F. Lehmanns Verl. München, 1955.;

Alekszandr Sirokorad: Korabli i Katera, VMF. SzSzSzR. 1939-1945. gg. Harreszt, Minszk, 2002.;

Sz. Sz. Berezsnoj: Korabli i Szuda VMF. VMF. SzSzSzR. 1928-1945. Voennoe Izdatelsztvo, Moszkva, 1988.;

Zicherman István: Tengerről az égbe. Anno Kiadó, Debrecen. é.n.;

G. A. Ammon - Sz.Sz. Berezsnoj: Geroicseszkie Korabli Rosszijszkogo i Szovetszkogo Voenno-Morszkogo Flotta, Voennizdat, Moszkva, 1981.;

David Fairhalt: Russia Looks to the Sea. Ebenezer Baylis\&Son Ltd., 1971, Worcester. 